Editorial

\title{
Does blindness count? Disability weights for vision loss
}

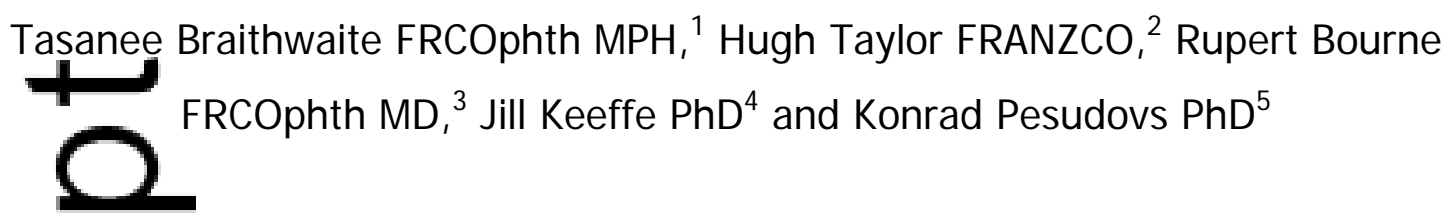

1. Moontrerds Eye Hospital, London, ECIV, UK

2. Melbourne School of Population Health, University of Melbourne, Melbourne, Austrafia

3. Visipn Eye Research Unit, Anglia Ruskin University, Cambridge, UK

4. LV Prasad Eye Institute, Hyderabad, India

5. NHMRC Centre for Clinical Eye Research, Flinders University, Adelaide, Australia

Flinde sutiversity

Corresdence: Dr Tasanee Braithwaite, Medical Retina Department, Moorfields

Eye varreal, 162 City Road, London, ECIV 2PD

Email asaneebraithwaite@gmail.com

Short unning title: Disability weights for vision loss

Receivaz J une 2016; accepted 6 November 2016

Conflict or interest: None

Fundin g sources: None

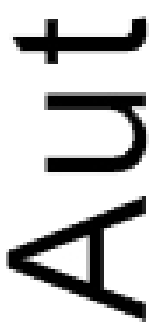

This is the author manuscript accepted for publication and has undergone full peer review but has not been through the copyediting, typesetting, pagination and proofreading process, which may lead to differences between this version and the Version of Record. Please cite this article as doi: $10.1111 /$ ceo.12874

This article is protected by copyright. All rights reserved. 
How important is blindness? Is being blind $17 \%(1)$ or $60 \%(2,3)$ as bad as being dead? MVore importantly, why is there such disagreement?

$\bigcirc$

These from disability weights. They were introduced by the Global Burdelor-Disease (GBD) Study (1990) to give a new population health measure, the disabil(ty aljusted life year (DALY).(2) DALYs aimed to capture a societal assessment of the pymgen of disease resulting from premature mortality and the non-fatal consequences of disease and injury.(2) Their concern was for social justice and the association between the health states resulting from disease, and lost welfare, subjecwellbeing and quality of life.(2) DALYs differed from quality adjusted life years (QALYS), which measure individual preferences for time spent in different health (5t)ts. (4) DALYs aimed to facilitate a more explicit and consistent comparison of heltcomes for health sector evaluation, and resource allocation.

DALYs are the sum of years of life lost (YLL) due to premature mortality and years lived vith disability (YLD). Calculation of the latter includes the disability weight - a number a scale from 0 to 1.0. A weight close to zero indicates a state of minimal impact, a weight close to 1.0 indicates a state so severe its impact is almost as bad as death. Disability weights are obtained from ordinal measurement of preference (paired health state comparisons). Advanced modeling transforms these data ing ints. To date, eight studies have estimated disability weights for blindness (Table 1),(5) using different approaches.(1-3, 6-10). These weights vary from in the original GBD study to 0.19 in the 2010 GBD study. This 3-fold reduction in the recent GBD disability weight reduces the apparent importance of 
cataract blindness $(11,12)$, questioning the validity of the disability weights. Applying the weights from the original and 2010 GBD studies gives very different estimates of the effectiveness of cataract surgery: In one study, from 2599 DALYs averted (disability weight 0.60 for blindness) to just 156 DALYs averted (disability weight 0.033 for moderate distance vision impairment).(13)

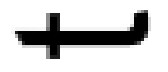

There number of possible explanations for the discrepancy. In our opinion, the mose sigmificant is the change from rating "disability" to rating "health". Health, as conceperentised by the World Health Organisation (WHO), is a multidimensional constr (1ct,) lefined as, "a state of complete physical, mental and social well-being and ngtry rely the absence of disease or infirmity." In the original GBD Study six weights captured 'loss of wellbeing'; blindness was assigned a weight of 0.60.(2) These wer defined in reference to limitations in ability to perform activities of procreation, occupation, education and recreation or needing assistance with activities or daily living. Fundamentally this is the measurement of disability. In contratt,t)e recent GBD Studies $(9,10)$ framed questions about 'loss of health'. Alth has resulted in only small changes to the disability weights for most disease ctetes, for disabling conditions, including vision and hearing loss, the reduction was dramatic, attributed by some to the change in construct $(14,15)$. This isgnot surprising; blind people often say, "I am not sick, I just can't see!” A secomactor is variability in the description of different effects of the "disease". The or ginal GBD Study (1990) defined blindness as, "maximal visual acuity of less than 3/60 yith the best possible correction," resulting in, "limited ability to perform most in all of the following areas: recreation, education, procreation or occupatron." (3) The recent GBD studies defined blindness as, "completely blind, whicea Ises great difficulty in some daily activities, worry and anxiety, and great difficulty going outside the home without assistance." (See Table 2$)(9,10)$ After 
criticism of some of the GBD 2010 disability weights, including those for vision loss,(14)(15) the GBD 2013 study tested a revised lay definition for some conditions. For example, the revised definition for deafness included a more explicit description of social isolation. When retested, the weight changed dramatically from 0.09 to 0.32 , leading to the conclusion that, "in some cases, responses are evidently highly sensitive to particular details in these descriptions".(10) The definition for blindness was ndedified in the GBD 2013 study and the weight changed negligibly, from 0.195 187, in comparison to that reported in the $\operatorname{GBD} 2010$ study. $(9,10)$

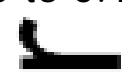

A third factor for the variability in disability weights may be the way questions were asked in lifferent studies. Comparing two health problems with different limitations requires complex judgment about which characteristics are more important.(10, 14) The recent GBD studies asked who, of two hypothetical people, was 'healthier' (See Table 10 ) A definition was given at the start, but not repeated for each of the 14 paireucomparisons, so respondents may not have retained the intended definitof 'health' all the way through.(14)

A fourtbector may be differences in the respondents in different studies. The original GBD study used medical or health experts. Others, including the recent GBD studie used members of the general public, with no expectation of understanding of healthrenditions, who may not have been population-representative.

A fifth factor may be the different valuation methods used; paired comparison, population,health equivalence, person trade off, or a visual analogue scale. The potentimpact of these different approaches is unknown. To add further potential confuston, the DALY itself is not a single measure, but combines YLL and YLD, which may arin with different combinations of data on prevalence, incidence, and life 
expectancy,(16) adding complexity when comparing conclusions from different studies. $(16,17)$

The downgrading of the disability weight for blindness has considerable consequences. Over the past two decades both the disability weight and the DALY have galned credence as important advocacy tools to highlight the burden and impad of dsease at a population level. DALYs and QALYs have been used in 825 nationes do demonstrate that surgical interventions are cost-effective global priorit Disability weights have been used to estimate the potential global produ (ivit) loss associated with uncorrected refractive error,(19) and with uncorrected presbyopia.(20) Multiple organisations advocate 'DALYs averted' as bottom-line performance metrics for guiding strategic and resource prioritisation decisions ivelation to competing public health interventions. $(21,22)$

In the anning of the global burden of DALYs by cause, the recent GBD Studies ranked ract and other blinding eye diseases much lower than in the original GBD stud sparking controversial debate, even between the GBD Core and Vision Loss Expert Groups. $(15,24)$ The ophthalmic community has been left in a state of understandable confusion. Which summary outcome measure should be preferred for adrocacy, benchmarking and resource allocation decisions at the population level? the DALY is a useful metric, which disability weight should be used to calculaton?

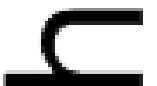

The $W H O$ bas not endorsed the recent GBD disability weight for blindness, given the significentand unexpected reduction in its value, and proposes an alternative weight of 0.3500 btained from modeling utility data.(25) Understanding the context of derivg lisability weights is important, as is recognising that the recent weight for blindness, 0.19 , represents a valuation of health loss rather than disability.(26) 
Further empirical research is needed to better understand societal valuations of blindness, by isolating the impact of what questions are asked and how, and through ensuring conceptual clarity on the key construct under investigation (is it disability or is it health?).

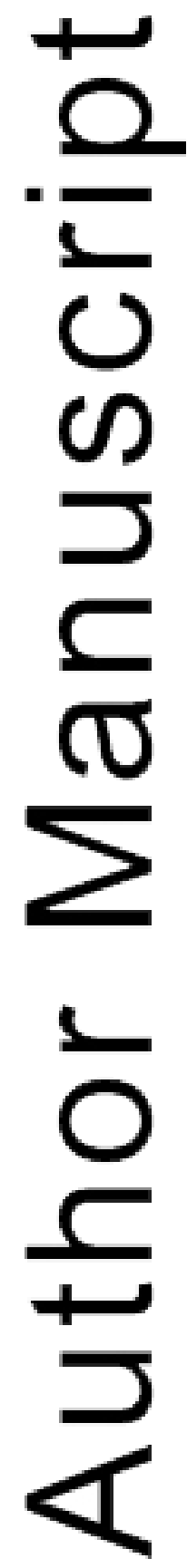

This article is protected by copyright. All rights reserved. 


\section{REFERENCES}

1. Haagsma J A, Maertens de Noordhout C, Polinder S, Vos T, Havelaar AH, Cassini A, et al. Assessing disability weights based on the responses of 30,660 people from four European countries. Population health metrics. 2015; 13:10. Epub 2016/U1/19.

2. Muray C . Quantifying the burden of disease: the technical basis for disabilifusted life years. Bulletin of the World Health Organization. 1994; ty 429-45. Epub 1994/01/01.

3. (Mur)ay CJ. Rethinking DALYs. In: Murray CJ, Lopez, A.D., editor. The global burdergfordisease: a comprehensive assessment of mortality and disability from diseases, injuries and risk factors in 1990 and projected to 2020. Cambridge, MA: Harvard University Press; 1996. p. 1-98.

4. of EQ-SU, SF-6D and TTO utility values to changes in vision and perceived visual functin $[$ in patients with primary open-angle glaucoma. BMC ophthalmology. 2012012012/08/23.

5. Heragsma J A, Polinder S, Cassini A, Colzani E, Havelaar AH. Review of disability weight studies: comparison of methodological choices and values. Population health metrics. 2014;12:20. Epub 2014/01/01.

6. Staythard ME, Essink-Bot, M.L., Bonsel, G.J. Disability weights for diseases: a modifiefotocol and results for a Western European region. European J ournal of Public Fealth. 2000; 10:24-30.

7. Haltyssen RM, Sanon M, Sommerfeld J, Wurthwein R. Obtaining disability weightrural Burkina Faso using a culturally adapted visual analogue scale. Health economics. 2002;11(2): 155-63. Epub 2002/03/29.

8. ك $\mathrm{T}$, Habicht J, Kiivet RA. Measuring burden of disease in Estonia to support public health policy. Eur J Public Health. 2009;19(5):541-7. Epub 2009/04/30. 
9. Salomon J A, Vos T, Hogan DR, Gagnon M, Naghavi M, Mokdad A, et al. Common values in assessing health outcomes from disease and injury: disability weights measurement study for the Global Burden of Disease Study 2010. Lancet. 2013;380(9859):2129-43. Epub 2012/12/19.

10. Salomon J A, Haagsma J A, Davis A, de Noordhout CM, Polinder S, Havelaar AH, etal. Disability weights for the Global Burden of Disease 2013 study. The Lancet Globalhealth. 2015;3(11):e712-23. Epub 2015/10/18.

11. - Vos T, Lozano R, Naghavi M, Flaxman AD, Michaud C, et al. Disabifry adjusted life years (DALYs) for 291 diseases and injuries in 21 regions, 1990-10 a systematic analysis for the Global Burden of Disease Study 2010. Lancet 2073; 380(9859):2197-223. Epub 2012/12/19.

12. Vos T, Flaxman AD, Naghavi M, Lozano R, Michaud C, Ezzati M, et al. Years lived with disability (YLDs) for 1160 sequelae of 289 diseases and injuries 19902010: 2013; 300(9859):2163-96. Epub 2012/12/19.

13. Catterjee S, Gosselin RA. Estimating the effectiveness of a hospital's interans in India: impact of the choice of disability weights. Bulletin of the World Heatch Organization. 2015;93(7):476-82. Epub 2015/07/15.

14. Nord E. Disability weights in the Global Burden of Disease 2010: Unclear meaning and overstatement of international agreement. Health Policy. 2013. Epub 2013/201/24.
Disabi ty weights for vision disorders in
2013:381(9860):23. Epub 2012/12/26.

16. disability-adjusted life years. Population health metrics. 2012;10(1):19. Epub 20120913. 
17. Voigt K, King NB. Disability weights in the global burden of disease 2010 study: two steps forward, one step back? Bulletin of the World Health Organization. 2014;92(3):226-8. Epub 2014/04/05.

18. Rios-Diaz AJ , Lam J, Ramos MS, Moscoso AV, Vaughn P, Zogg CK, et al. Global Patterns of QALY and DALY Use in Surgical Cost-Utility Analyses: A Systematic Reviêt. PóS one. 2016; 11(2): e0148304. Epub 2016/02/11.

19. Smin TS, Frick KD, Holden BA, Fricke TR, Naidoo KS. Potential lost produ resulting from the global burden of uncorrected refractive error. Bulletin of the Health Organization. 2009;87(6):431-7. Epub 2009/07/01.

20. Fric KD, J oy SM, Wilson DA, Naidoo KS, Holden BA. The Global Burden of Potential Roductivity Loss from Uncorrected Presbyopia. Ophthalmology. 2015. Epub

21. Lonffield K, Smith B, Gray R, Ngamkitpaiboon L, Vielot N. Putting health metric practice: using the disability-adjusted life year for strategic decision making. DIMC public health. 2013;13 Suppl 2:S2. Epub 2013/08/09.

22. Gbrey K, Sinclair M, O'Toole J, Leder K. Using disability-adjusted life years to set realth-based targets: a novel use of an established burden of disease metric. J ournalefpublic health policy. 2013;34(3):439-46. Epub 2013/05/31.

23. Murray CJ, Barber RM, Foreman KJ, Abbasoglu Ozgoren A, Abd-Allah F, Abera SF, et l. Global, regional, and national disability-adjusted life years (DALYs) for 306 diseaserand injuries and healthy life expectancy (HALE) for 188 countries, 19902013: quantifying the epidemiological transition. Lancet. 2015;386(10009):2145-91. Epub 015/09/01.

24. Salomon J A, Vos T, Murray CJ. Disability weights for vision disorders in Global Burde Pisease study - Authors' reply. Lancet. 2013;381(9860):23-4. Epub 2012/12/Z6.

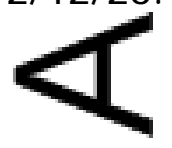


25. Department of Health Statistics and Information Systems WHO G. WHO methods and data sources for global burden of disease estimates 2000-2011. Geneva: World Health Organization, 2013.

26. Nord E. Uncertainties about disability weights for the Global Burden of Disease study. The Lancet Global health. 2015;3(11):e661-2. Epub 2015/10/18.

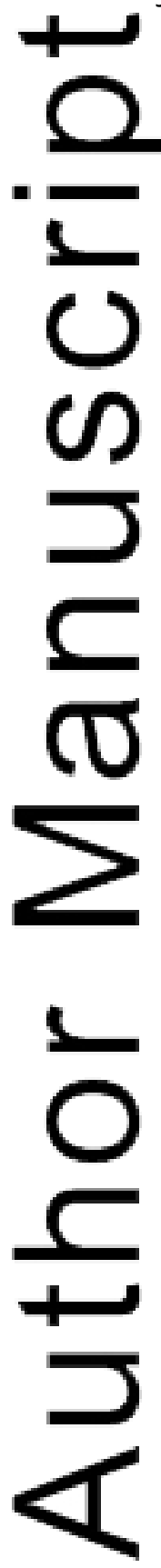




\section{TABLES}

Table 1: Summary of studies estimating a disability weight for blindness

\begin{tabular}{|c|c|c|c|c|c|c|c|c|}
\hline First author & Year & Region & Panel & n panel & $\begin{array}{l}\text { n } \\
\text { health } \\
\text { states }\end{array}$ & $\begin{array}{l}\text { Valuation } \\
\text { methods }\end{array}$ & $\begin{array}{l}\text { DW (95\% } \\
\text { Cl) }\end{array}$ & $\begin{array}{l}\text { Construct } \\
\text { in the } \\
\text { question }\end{array}$ \\
\hline Murray(2) & & Global & $\begin{array}{l}\text { Independent } \\
\text { experts }\end{array}$ & NS & 6 & $\begin{array}{l}\text { Magnitude } \\
\text { estimation }\end{array}$ & 0.6 & Disability \\
\hline $\begin{array}{l}\text { Murray GBD } \\
1990(3)\end{array}$ & & Global & $\begin{array}{l}\text { Medical } \\
\text { experts }\end{array}$ & 10 & 483 & $\begin{array}{l}\text { PTO and } \\
\text { VAS }\end{array}$ & $\begin{array}{l}0.6(0.50- \\
0.70)\end{array}$ & Disability \\
\hline Stouthard (6) & & Netherlands & $\begin{array}{l}\text { Medical } \\
\text { experts }\end{array}$ & 38 & 175 & $\begin{array}{l}\text { PTO and } \\
\text { VAS }\end{array}$ & $\begin{array}{l}0.43(0.34- \\
0.52)\end{array}$ & Disability \\
\hline Baltussen (7) & & $\begin{array}{l}\text { Burkina } \\
\text { Fasso }\end{array}$ & $\begin{array}{l}\text { Health } \\
\text { professionals, } \\
\text { Population }\end{array}$ & $\begin{array}{l}39 \text { lay } \\
\text { people, } \\
17 \\
\text { health } \\
\text { workers }\end{array}$ & 9 & $\begin{array}{l}\text { Culturally } \\
\text { adapted VAS }\end{array}$ & 0.36 & Disability \\
\hline Lai (8) & & Estonia & $\begin{array}{l}\text { Medical } \\
\text { experts }\end{array}$ & 25 & 283 & $\begin{array}{l}\text { PTO and } \\
\text { VAS }\end{array}$ & 0.478 & Disability \\
\hline $\begin{array}{l}\text { Salomon GBD } \\
2010 \text { (9) }\end{array}$ & & Global & $\begin{array}{l}\text { Population- } \\
\text { based } \\
\text { samples }\end{array}$ & 30,230 & 220 & $\mathrm{PC}$ and $\mathrm{PHE}$ & $\begin{array}{l}0.195 \\
(0.132- \\
0.272)\end{array}$ & Health loss \\
\hline $\begin{array}{l}\text { Haagsma } \\
\text { GBD Europe } \\
\text { (1) }\end{array}$ & & $\begin{array}{l}\text { Europe (4): } \\
\text { Sweden, } \\
\text { Italy, } \\
\text { Netherlands, } \\
\text { Hungary }\end{array}$ & $\begin{array}{l}\text { Population } \\
\text { (quota } \\
\text { sampling of } \\
\text { internet } \\
\text { panels, } \\
\text { population } \\
\text { representative } \\
\text { 18-65 years) }\end{array}$ & 30,660 & 255 & $\mathrm{PC}$ and PHE & $\begin{array}{l}0.173(0.145 \\
-0.213)\end{array}$ & Health loss \\
\hline $\begin{array}{l}\text { Salomon GBD } \\
2013 \text { (10) }\end{array}$ & 8015 & Global & $\begin{array}{l}\text { Population } \\
\text { (combined } \\
\text { data) }(7,8)\end{array}$ & 60,890 & $\begin{array}{l}183 \text { or } \\
235\end{array}$ & PC & $\begin{array}{l}0.187(0.124 \\
-0.260)\end{array}$ & Health loss \\
\hline
\end{tabular}

GBD = Global Burden of Disease, PC = Paired comparison, NS= Not specified, PTO=person trade off, VAS=visual analog scale, PHE = Population Health

Equivalence 


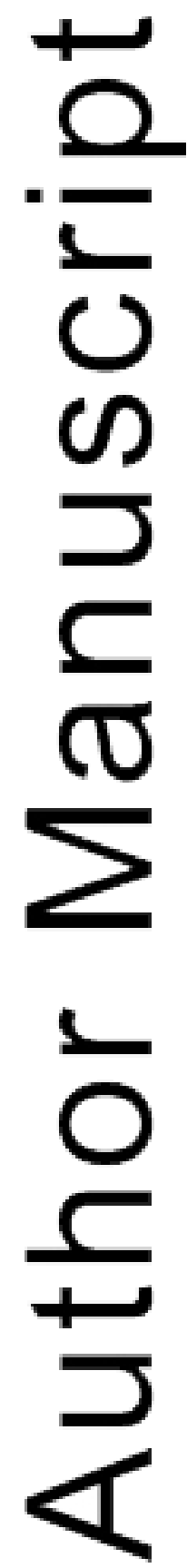

This article is protected by copyright. All rights reserved. 
Table 2: Example of paired comparison question used in GBD 2013 Study(10) to determine a disability weight for two disease effects, distance vision blindness and severe neck pain

\begin{tabular}{|c|c|}
\hline Example of GBD 2013 Paired comparison question & $\begin{array}{l}\text { GBD } 2013 \text { disease } \\
\text { effect and disability } \\
\text { weight }\end{array}$ \\
\hline 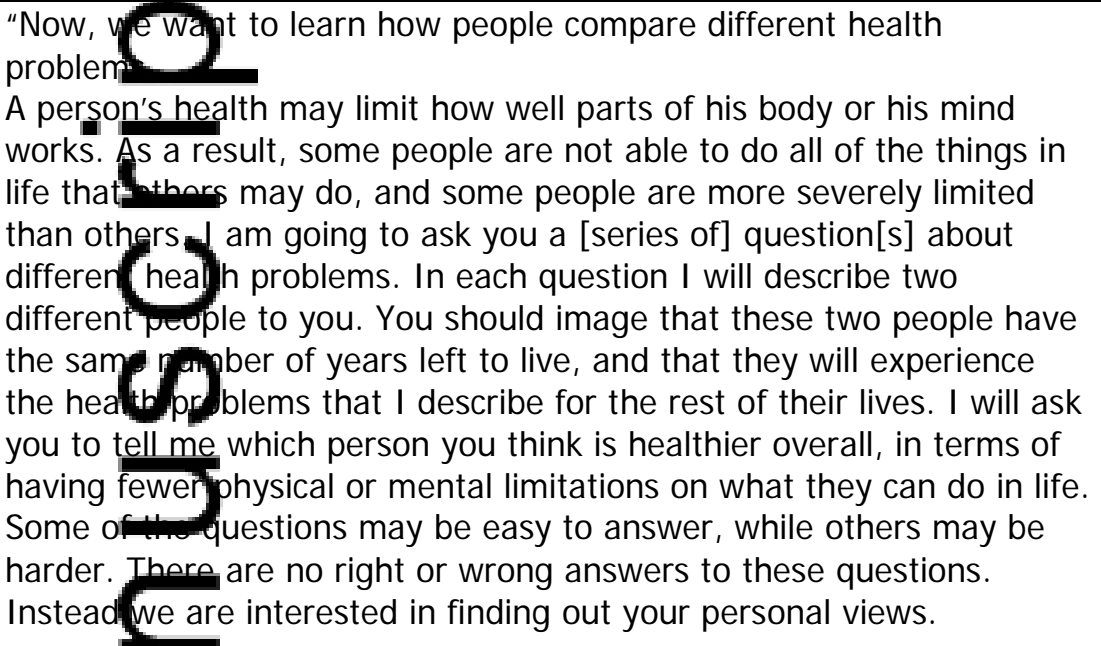 & \\
\hline $\begin{array}{l}\text { The first } \\
\text { some dily is completely blind, which causes great difficulty in } \\
\text { outside the home without assistance }\end{array}$ & $\begin{array}{l}\text { Distance vision blindness } \\
0.187(0.124-0.260)\end{array}$ \\
\hline $\begin{array}{l}\text { The seconarson has constant neck pain and arm pain, and difficulty } \\
\text { turniphe head, holding arms up, and lifting things. The person gets } \\
\text { headaches, sleeps poorly, and feels tired and worried }\end{array}$ & $\begin{array}{l}\text { Severe neck pain } \\
0.304(0.202-0.415)\end{array}$ \\
\hline
\end{tabular}

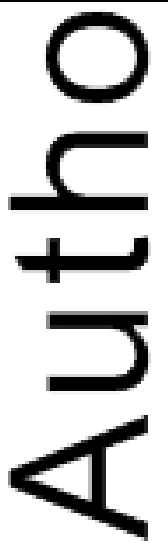

This article is protected by copyright. All rights reserved. 


\section{University Library}

\section{- M M N E R VA A gateway to Melbourne's research publications}

Minerva Access is the Institutional Repository of The University of Melbourne

Author/s:

Braithwaite, T;Taylor, H;Bourne, R;Keeffe, J;Pesudovs, K

Title:

Does blindness count? Disability weights for vision loss

Date:

2017-04-01

Citation:

Braithwaite, T., Taylor, H., Bourne, R., Keeffe, J. \& Pesudovs, K. (2017). Does

blindness count? Disability weights for vision loss. CLINICAL AND EXPERIMENTAL OPHTHALMOLOGY, 45 (3), pp.217-220. https://doi.org/10.1111/ceo.12874.

Persistent Link:

http://hdl.handle.net/11343/292728 